\title{
Group B streptococci in pharyngeal aspirates at birth and the early detection of neonatal sepsis
}

\author{
MARY P. E. SLACK AND R. T. MAYON-WHITE \\ From the Department of Bacteriology and Regional Public Health Laboratory, \\ Radcliffe Infirmary, Oxford
}

SUMMARY The pharyngeal aspirates collected from 400 babies at the time of delivery were examined for the presence of bacteria, especially group B streptococci. Aspirates from 79 babies were found to contain viable bacteria, including 4 with group B streptococci; one of these 4 babies developed streptococcal meningitis within 24 hours. The group B streptococci were seen on a Gram-stained film of the aspirate, and were detectable by coagglutination and countercurrent immunoelectrophoresis within 4 hours and by culture after 24 hours. Examination of pharyngeal aspirates may be of value as a screening test for neonatal sepsis.

It is usual practice to suck the mixture of amniotic fluid, prenatal respiratory secretions, and maternal vaginal surface material out of the mouth and nose of a baby immediately after delivery. This mixture, the pharyngeal aspirate, may be useful in the early diagnosis of neonatal infection because any bacteria present must have been acquired during the first or second stage of labour. We report bacteriological observations on $\mathbf{4 0 0}$ pharyngeal aspirates examined for the presence of group $B$ streptococci.

Group B streptococcal infection has become an important cause of morbidity and mortality in the neonate (Hood et al., 1961; Eickhoff et al., 1964) and in some reports it is the most important cause of neonatal mortality (Yow, 1974). Two types of illness have been described (Baker et al., 1973; Franciosi et al., 1973). The early form of infection can progress rapidly and cause diagnostic confusion with hyaline membrane disease (Ablow et al., 1976). Between 60 and $75 \%$ of the babies die, often within 48 hours of the onset of infection. As infection can occur so soon after birth it seems probable that the baby is infected either in utero or as it passes down the birth canal. The standard laboratory methods of culture and serological identification of group B streptococci may fail to give an answer in time to affect clinical management. Serological identification of group B streptococci can be performed rapidly using countercurrent immunoelectrophoresis (CIE) (Dajani, 1973; Hill et al., 1975) or coagglutination.

Received 9 January 1978
In this study these techniques were added to bacteriological microscopical examination and culture.

\section{Materials and methods}

All babies studied were born at the John Radcliffe Hospital, Oxford, between April and June 1977. The pharyngeal aspirates with volumes of between 0.2 and $15 \mathrm{ml}$ were collected by midwives at the time of delivery using a sterile disposable mucus extractor (Macrae mucus extractor, Warne Surgical Products) as was their usual practice. There was one specimen for each child. 156 specimens were stored at $4^{\circ} \mathrm{C}$ and the other 244 specimens at $-20^{\circ} \mathrm{C}$ (for reasons related to a different study) until examination, which was usually made within 24 hours.

To assess the effect of the two different storage conditions, sterile aspirates were pooled and divided into a series of $0.5 \mathrm{ml}$ samples. Overnight broth cultures of three representative organisms (Staphylococcus albus, Escherichia coli, and group B streptococcus) were inoculated into the samples to give a final concentration of approximately $10^{3}$ organisms per $\mathrm{ml}$. Viable bacterial counts were performed using a standard loop $(0.02 \mathrm{ml})$. The numbers of bacteria were estimated at zero, 6, 24, 48 , and 96 hours in samples stored at $4^{\circ} \mathrm{C}$ or at $-20^{\circ} \mathrm{C}$, and in one set of samples that were repeatedly thawed and refrozen to $-20^{\circ} \mathrm{C}$ at the four times after zero. The group B streptococcus survived very well and was resistant to repeated thawing and freezing. The $E$. coli was however adversely affected by freezing, being rapidly killed by this procedure (Figure). 

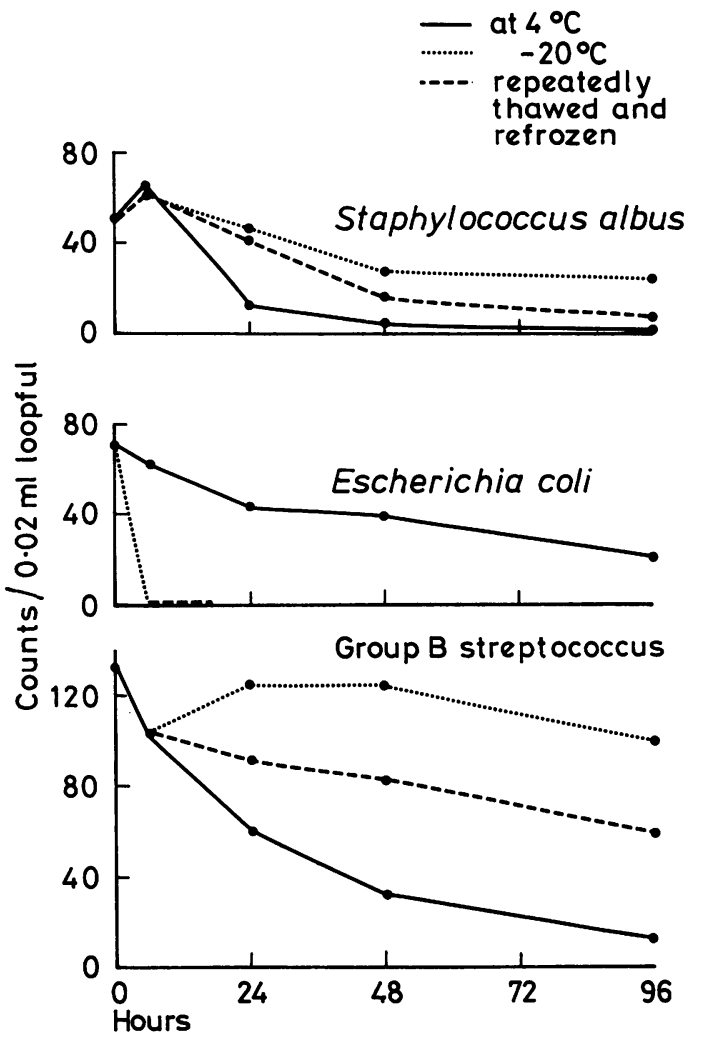

Figure The survival of bacteria in pharyngeal aspirates, average counts in four specimens of pooled aspirate stored.

\section{Examination of pharyngeal aspirates}

A Gram-stained film was made of each pharyngeal aspirate and examined for the presence of organisms and polymorphonuclear leucocytes (pus cells). The material was cultured aerobically and anaerobically on blood agar and on MacConkey agar. All cultures were incubated at $37^{\circ} \mathrm{C}$ for 18 hours and then were reincubated for another day if no growth had appeared. All organisms isolated were identified, using Lancefield's method to group $\beta$-haemolytic streptococci (Lancefield, 1933).

The pharyngeal aspirate was also added to $1 \mathrm{ml}$ Todd Hewitt broth and incubated at $37^{\circ} \mathrm{C}$ for 4 hours at which time CIE and coagglutination were performed, using group B streptococcal antisera. If these tests were negative, they were repeated 20 hours later after making subcultures on to blood agar and MacConkey agar. CIE was performed by the method of El-Refaie and Dulake (1975) using Burroughs Wellcome group B streptococcal antisera. Positive and negative controls for both antigen and antiserum were included on every slide. Coagglutination was performed on glass slides using group B streptococcal antisera combined with staphylococci (Phadebact, Pharmacia). If the aspiratebroth culture was too mucinous for slide agglutination, the test was repeated after treating the culture with an equal volume of $2 \% \mathrm{~N}$-acetyl-Lcysteine for one hour. 73 aspirates $(18 \cdot 25 \%)$ were tested by CIE and coagglutination before culture. In this case, the aspirate was shaken with an equal volume of L-cysteine for 15 minutes before testing.

\section{Results}

Altogether 400 babies were studied (203 boys and 197 girls), of whom 265 had had normal deliveries and been born within 12 hours of the membranes rupturing. The remainder had had at least one complication of labour (Table 1). There were 6 pairs of twins. The birthweights ranged from 1.80 to $4.73 \mathrm{~kg}$; 17 babies weighed less than $2.50 \mathrm{~kg}$ and 8 babies were born after less than 37 weeks of gestation.

244 pharyngeal aspirates were frozen and stored at $-20^{\circ} \mathrm{C}$ before examination, and 156 were kept at $4^{\circ} \mathrm{C}$. The examination of the Gram-stained films showed no pus or organisms in 288 out of the 400 aspirates. Pus cells alone were seen in 22 aspirates, bacteria alone in 75, and pus and bacteria in 15 . Only 5 aspirates had numerous Gram-positive cocci to be seen in microscopical examination, and all 5 subsequently grew streptococci (4 group B and 1 enterococcus).

On culture, bacteria were isolated from $79(19 \%)$ aspirates, 72 within 24 hours of incubation (Table 2). In 11 of these 79, the presence of these organisms was undetected in the Gram-stained film; conversely there were 22 aspirates with organisms seen on microscopical examination and no growth on culture. The observation of pus cells was not related to the culture results.

Bacteria were isolated from $44(17 \%)$ of the 265 babies born by normal delivery within 12 hours of labour, and from $35(26 \%)$ of the 135 babies born by abnormal deliveries or after prolonged labour, a significant difference $\left(\chi^{2}=4 \cdot 33\right.$, df $\left.=1, P<0 \cdot 05\right)$. Most of this difference stems from the high rate of isolation (35\%) from the babies born within 12 hours per vaginam with instrumentation, and babies with normal deliveries after 12 hours; but the small number of babies in some groups and the mixture of organisms isolated precluded detailed analysis.

Four babies were found to have group B streptococci in their pharyngeal aspitates.

Case 1. A term baby boy of $3 \cdot 40 \mathrm{~kg}$ and delivered by means of Neville Barnes forceps after the mem- 
Table 1 Duration of labour and mode of delivery of 400 babies

\begin{tabular}{|c|c|c|c|c|}
\hline \multirow{2}{*}{ Mode of delivery } & \multicolumn{4}{|c|}{ Interval from rupture of membranes to delivery } \\
\hline & $<12$ hours & 12-24 hours & $>24$ hours & Total \\
\hline $\begin{array}{l}\text { Normal vaginal delivery } \\
\text { Forceps } \\
\text { Ventouse }\end{array}$ & $\begin{array}{c}265(44) \\
47(17) \\
1\end{array}$ & $\begin{array}{r}17(7) \\
28(4) \\
2(2)\end{array}$ & $\begin{array}{l}3 \\
4(1) \\
1\end{array}$ & $\begin{array}{l}285(51) \\
79(22) \\
4(2)\end{array}$ \\
\hline $\begin{array}{l}\text { Caesarean section } \\
\text { Elective } \\
\text { Emergency }\end{array}$ & $\begin{array}{l}10(2) \\
17(2)\end{array}$ & $\overline{3}$ & $\overline{2}$ & $\begin{array}{l}10(2) \\
22(2)\end{array}$ \\
\hline Total number of babies & $340(65)$ & $50(13)$ & $10(1)$ & $400(79)$ \\
\hline
\end{tabular}

Number of babies with bacteria grown from their aspirate is given in parentheses.

Table 2 Organisms isolated from 400 pharyngeal aspirates

\begin{tabular}{|c|c|c|}
\hline \multirow[b]{2}{*}{ Organism } & \multicolumn{2}{|c|}{ Number of isolates from } \\
\hline & $\begin{array}{l}244 \text { samples } \\
\text { stored at }-20^{\circ} \mathrm{C}\end{array}$ & $\begin{array}{l}156 \text { samples } \\
\text { stored at } 4^{\circ} \mathrm{C}\end{array}$ \\
\hline $\begin{array}{l}\text { Coagulase-negative } \\
\text { staphylococci } \\
\text { E. coli } \\
\text { Klebsiella sp. } \\
\text { Enterococci } \\
\text { Nonhaemolytic streptococci } \\
\text { Group B streptococci } \\
\text { a-haemolytic streptococci } \\
\text { Candida albicans } \\
\text { Diphtheroids } \\
\text { Total number of samples }\end{array}$ & $\begin{array}{c}32(13.1 \%) \\
4(1.6 \%) \\
0 \\
4(1.6 \%) \\
7(2.9 \%) \\
2(0.8 \%) \\
11(4.5 \%) \\
0 \\
0\end{array}$ & $\begin{array}{r}12(7 \cdot 7 \%) \\
9(5 \cdot 8 \%) \\
1(0.6 \%) \\
2(1.3 \%) \\
1(0.6 \%) \\
2(1.3 \%) \\
2(1.3 \%) \\
2(1.3 \%) \\
1(0.6 \%)\end{array}$ \\
\hline
\end{tabular}

10 aspirates grew a mixture of coagulase-negative staphylococci and either nonhaemolytic streptococci or $\alpha$-haemolytic streptococci. (3 aspirates grew a mixture of $\alpha$-haemolytic and nonhaemolytic streptococci). 1 aspirate grew both group B streptococci and E. coli. 1 aspirate grew both Klebsiella and enterococci.

branes had been ruptured for 23 hours. The Apgar :core at 0 minutes was $9 / 10$. Type Ib group B streptococci were isolated. The baby remained well until his discharge home on the second day. No other swabs were taken.

Case 2. A baby boy of 39 weeks' gestation weighing $2.89 \mathrm{~kg}$ was a breech presentation delivered using Neville Barnes forceps to the after-coming head. The membranes were ruptured for 14 hours. At 0 minutes Apgar score was 9/10 and the baby's condition was satisfactory. Within 24 hours he had developed meningitis, which responded to benzylpenicillin. Type Ib group B streptococci were isolated from the pharyngeal aspirate, blood, cerebrospinal fluid, nose, skin, and rectum, and the mother's vagina.

Case 3. A term baby girl of $2.66 \mathrm{~kg}$ was delivered after the membranes had been ruptured for $2 \frac{1}{4}$ hours, following Keilland's rotation. The Apgar score at 0 minutes was 9/10. Type II group B streptococci were isolated. The baby, who was deeply jaundiced, was treated with benzylpenicillin. No other swabs were taken and the baby was discharged well on the eighth day.

Case 4. A term baby boy of $3.59 \mathrm{~kg}$ was delivered normally after the membranes had been ruptured for $6 \frac{1}{2}$ hours with an Apgar score at 0 minutes of $8 / 10$. Type II group B streptococci were isolated, no other swabs being taken. The baby remained well and was discharged on the third day.

Coagglutination and CIE for group B streptococci were strongly positive after 4 hours in all 4 cases before the organism was identified on agar cultures. Two of these 4 aspirates were positive by coagglutination and CIE when tested before inoculation into broth cultures-that is within an hour of receipt of the specimen-but the other two were not tested at that time. None of the remaining 396 babies was known to be colonised by group B streptococci or to develop 'early onset' infection. None of the babies developed a recognised illness caused by the other potentially pathogenic organisms (enterococci, enterobacteria, and C. albicans) which were isolated.

Enterobacteria were isolated from significantly more of the aspirates stored at $4^{\circ} \mathrm{C}(10$ out of 156) than of those frozen to $-20^{\circ} \mathrm{C}$ (4 out of 244) $\left(\chi^{2}=5 \cdot 08, d f=1, P<0 \cdot 025\right)$. In 9 frozen samples, Gram-negative rods were seen on microscopical examination but failed to grow on subsequent culture. This occurred in only 2 aspirates kept at $4^{\circ} \mathrm{C}$.

18 babies were found to have $\alpha$-haemolytic or nonhaemolytic streptococci in their pharyngeal aspirates, including 10 who had a mixture of these organisms and coagulase-negative staphylococci. 4 babies with only coagulase-negative staphylococci in their aspirates had been born by caesarean section, 2 electively and 2 after the membranes had ruptured.

\section{Discussion}

The findings show that the material aspirated at delivery from the nose and mouth is usually sterile. 
Other observers (Kneeland, 1930; Torrey and Reese, 1945; Smith and Bloomfield, 1950) have shown that there is usually no growth from throat swabs taken immediately after delivery, but Cornelison et al. (1946) found that bacteria were more common in specimens from babies after difficult deliveries. The aspirate may be sterile because it collects in the pharynx before delivery and because little of the flora of the vagina enters the mouth or nose during delivery (Torrey and Reese, 1944). It is possible that antimicrobial solutions used to cleanse the perineum and vagina before delivery reduce the number of viable bacteria in the aspirated material and amniotic fluid may have antimicrobial properties (Galask and Snyder, 1968).

We considered whether the aspirates could have been contaminated by the midwives during collection, particularly as from 18 aspirates we grew organisms that might well have been part of their normal mouth flora. However, 20 laboratory staff, untrained in nursing techniques, used the mouth suction apparatus to aspirate sterile Todd Hewitt broth and no contamination occurred.

Storage of two-thirds of the aspirates at $-20^{\circ} \mathrm{C}$ must have affected the overall isolation rate of enterobacteria $(3.5 \%)$, and we believe that the figure of $5.8 \%$ isolated from the 156 unfrozen specimens is the better estimate of the actual prevalence. On the other hand, group B streptococci survive well under both conditions of storage, so that a collection of aspirates stored at $-20^{\circ} \mathrm{C}$ for other purposes could be examined for these bacteria. Our methods did not include special media for lactobacilli, which may partly explain their absence from our findings. However, Gram-positive bacilli were rarely seen on microscopical examination, and never in large numbers.

It has been reported that 'early onset' disease caused by group B streptococci is associated with low birthweight, prolonged rupture of the membranes, and congenital abnormalities (Eickhoff et al., 1964; Bergqvist et al., 1971). However, many of the babies who develop fulminating infection have no such predisposing factors, and most babies colonised by group B streptococci remain well. On the one hand, $3 \%$ of babies have group B streptococci in the external ear, on the skin, or in the nose soon after birth (Ferrieri et al., 1977). On the other hand, the reported incidence of group B streptococcal disease in the newborn is between 1 and 3 per 1000 live births (Baker and Barrett, 1973; Howard and McCracken, 1974). A method for the early detection of group B streptococcal infection might assist in the prevention of this important neonatal disease. Other materials have been examined for an early diagnosis of neonatal sepsis: gastric contents
(Blanc, 1961; Ramos and Stern, 1969; Yeung and Tam, 1972), umbilical cord tissue (Bernischke and Clifford, 1959; Overbach et al., 1970), and external ear contents (Scanlon, 1971). Although Mims et al. (1972) suggested that an analysis of the gastric contents was no more helpful than clinical criteria in selecting infants at high risk of infection, Echeverria (1973) and Ablow et al. (1976) found that Gram-stained films of gastric aspirates could assist in the diagnosis of established streptococcal disease. It may become possible to identify those babies at risk by measuring maternal antibodies (Baker and Kasper, 1976) and so concentrate preventive measures on high risk groups. In the management of babies at special risk of neonatal sepsis, it would be suspected that bacteria in the respiratory tract at the time of the first inhalation would be more likely to casuse systematic disease than those on the skin. Pharyngeal aspirates have not previously been investigated as a possible means of making an early diagnosis of group B streptococcal infection. As the material is already collected routinely into sterile containers, it would be a convenient specimen to examine (instead of discarding it as at present). As we have shown, group B streptococci were present in large numbers in the pharyngeal aspirates of $1 \%$ of our series of babies, and can be detected in broth cultures within 4 hours of incubation. We are not certain of the pathological significance of this observation as our technique cannot distinguish carriage from epithelial invasion. We believe that the predictive value of these and related questions about cost-benefit can be determined only if pharyngeal aspirates are examined in future studies of group B streptococcal disease and other neonatal infections. Selective media for group B streptococci may not increase the yield of this organism because most of the aspirates were sterile. CIE and coagglutination are probably too time-consuming to apply on a large scale but the Gram-stained film would be a cheap and quick method for screening a large number of specimens.

We thank Dr R. G. Mitchell for his support and for bacteriological data for Case 2; Dr J. D. Baum and the midwives at the John Radcliffe Hospital for assistance in collecting aspirates; Mrs J. Stringer at the Cross Infection Reference Laboratory, Colindale for typing the streptococci, and Mr F. C. Saunders, Oxford Public Health Laboratory, for technical assistance. Phadebact reagents were donated by Pharmacia (Great Britain) Ltd.

\author{
References \\ Ablow, R. C., Driscoll, S. G., Effmann, E. L., Gross, I., \\ Jolles, C. J., Uauy, R., and Warshaw, J. B. (1976). A
}


comparison of early onset group B streptococcal neonatal infection and the respiratory distress syndrome of the newborn. New England Journal of Medicine, 294, 65-70.

Baker, C. J., and Barrett, F. F. (1973). Transmission of group B streptococci among parturient women and their neonates. Journal of Pediatrics, 83, 919-925.

Baker, C. J., Barrett, F. F., Gordon, R. C., and Yow, M. D. (1973). Suppurative meningitis due to streptococci of Lancefield group B: a study of 33 infants. Journal of Pediatrics, 82, 724-729.

Baker, C. J., and Kasper, D. L. (1976). Correlation of maternal antibody deficiency with susceptibility to neonatal group B streptococcal infection. New England Journal of Medicine, 294, 753-756.

Bergqvist, G., Hurvell, B., Malmborg, A. S., Rylander, M., and Tunell, R. (1971). Neonatal infections caused by group B streptococci. Scandinavian Journal of Infectious Diseases, 3, 157-162.

Bernischke, K., and Clifford, S. H. (1959). Intrauterine bacterial infection of the newborn infant. Frozen sections of the cord as an aid to early detection. Journal of Pediatrics, $54,11-18$.

Blanc, W. A. (1961). Pathways 'of fetal and early neonatal infection. Viral placentitis, bacterial and fungal chorioamniotitis. Journal of Pediatrics, 59, 473-496.

Cornelison, J. L., Johnson, E. A., and Fischer, W. M. (1946). Bacteriology of the oronasal cavity of the newborn. American Journal of Obstetrics and Gynecology, 52, 797-802.

Dajani, A. S. (1973). Rapid identification of beta-hemolytic streptococci by counterimmunoelectrophoresis. Journal of Immunology, 110, 1702-1705.

Echeverria, P. (1973). Observations concerning infections with beta hemolytic streptococci, not group $A$ or $D$, in neonates. Journal of Pediatrics, 83, 499-500.

Eickhoff, T. C., Klein, J. O., Daly, A. K., Ingall, D., and Finland, M. (1964). Neonatal sepsis and other infections due to group B beta-hemolytic streptococci. New England Journal of Medicine, 271, 1221-1228.

El-Refaie, M., and Dulake, C. (1975). Counter-current immunoelectrophoresis for the diagnosis of pneumococcal chest infection. Journal of Clinical Pathology, 28, 801-806.

Ferrieri, P., Cleary, P. P., and Seeds, A. E. (1977). Epidemiology of group B streptococcal carriage in pregnant women and newborn infants. Journal of Medical Microbiolog.v, 10, 103-114.

Franciosi, R. A., Knostman, J. D., and Zimmerman, R. A. (1973). Group B streptococcal neonatal and infant infections. Journal of Pediatrics, 82, 707-718.

Galask, R. P., and Snyder, I. S. (1968). Bacterial inhibition by amniotic fluid. American Journal of Obstetrics and Gynecology, 102, 949-955.

Hill, H. R., Riter, M. E., Menge, S. K., Johnson, D. R., and Matsen, J. M. (1975). Rapid identification of group B streptococci by counterimmunoelectrophoresis. Journal of Clinical Microbiology, 1, 188-191.

Hood, M., Janney, A., and Dameron, G. (1961). Betahemolytic streptococcus group B associated with problems of the perinatal period. American Journal of Obstetrics and Gynecology, 83, 809-818.

Howard, J. B., and McCracken, G. H., Jr (1974). The spectrum of group B streptococcal infection in infancy. American Journal of Diseases of Children, 128, 815-818.

Kneeland, Y., Jr (1930). Studies on the common cold. III. The upper respiratory flora of infants. Journal of Experimental Medicine, 51, 617-624.

Lancefield, R. C. (1933). A serological differentiation of human and other groups of hemolytic streptococci. Journal of Experimental Medicine, 57, 571-595.

Mims, L. C., Medawar, M. S., Perkins, J. R., and Grubb, W. R. (1972). Predicting neonatal infections by evaluation of the gastric aspirate: a study in two hundred and seven patients. American Journal of Obstetrics and Gynecology, 114, 232-238.

Overbach, A. M., Daniel, S. J., and Cassady, G. (1970). The value of umbilical cord histology in the management of potential perinatal infection. Journal of Pediatrics, 76, 22-31.

Ramos, A., and Stern, L. (1969). Relationship of premature rupture of the membranes to gastric fluid aspirate in the newborn. American Journal of Obstetrics and Gynecology, 105, 1247-1251.

Scanlon, J. (1971). The early detection of neonatal sepsis by examination of liquid obtained from the external ear canal. Journal of Pediatrics, 79, 247-249.

Smith, J. W., and Bloomfield, A. L. (1950). The development of the aerobic bacterial flora of the throat in newborn babies. Journal of Pediatrics, 36, 51-60.

Torrey, J. C., and Reese, M. K. (1944). Initial aerobic flora of newborn (premature) infants. Nature, source and relation to ultraviolet irradiation and face masks. American Journal of Diseases of Children, 67, 89-99.

Torrey, J. C., and Reese, M. K. (1945). Initial aerobic flora of newborn infants. Selective tolerance of the upper respiratory tract for bacteria. American Journal of Diseases of Children, 69, 208-214.

Yeung, C. Y., and Tam, A. S. Y. (1972). Gastric aspirate findings in neonatal pneumonia. Archives of Disease in Childhood, 47, 735-740.

Yow, M. (1974). Group B streptococci: a serious threat to the neonate. Journal of the American Medical Association, 230, 1177-1178.

Correspondence to Dr M. P. E. Slack, Department of Bacteriology, Gibson Laboratories, The Radcliffe Infirmary, Oxford OX2 6HE. 